\title{
Hormonal crosstalk in the regulation of meristem activity and the phyllomorph architecture in Streptocarpus (Gesneriaceae): a review
}

\author{
Nishii K..$^{1,2}$, Spada A. ${ }^{3}$ \& M. Möller ${ }^{1 *}$ \\ ${ }^{1}$ Royal Botanic Garden Edinburgh, 20A Inverleith Row, Edinburgh, Scotland, EH3 5LR, UK. \\ 2 Kanagawa University, 2946, Tsuchiya, Hiratsuka-shi, Kanagawa, 259-1293, Japan \\ ${ }^{3}$ Milan University Dipartimento Scienze Agrarie e Ambientali territorio e Agroenergia, \\ Universita' degli Studi di Milano, Via Celoria 2, Milano - 20133, Italy \\ *E-mail: mmoeller@rbge.org.uk
}

\begin{abstract}
Plants belonging to the family Gesneriaceae exhibit great diversity in shoot architecture. One genus within the family, Streptocarpus, encompasses species with different body plans that do not conform to the standard bauplan of angiosperms. These include features such as 'anisocotyly', the unequal cotyledon morphogenesis, and the 'phyllomorph' a leaf/shoot construct of which the development is governed by three meristems (groove meristem, petiolode meristem, basal meristem). In the extreme case, the plants only consist of one hugely enlarged cotyledon ('unifoliate' habit). Modification in the position and activities of the meristem are responsible for the morphological flexibility of the genus. This review summarises the interactions between hormones and developmental genes and compares these to model plants. Some mechanisms controlled by class 1 KNOX (KNOX1) genes appear to be conserved between plants with ordinary shoots and the Streptocarpus phyllomorph, while others have diverged. In particular, cytokinins and gibberellins appear to be important for meristem regulation to establish anisocotyly and the development of phyllomorphs in Streptocarpus through KNOX1 regulation. This is supported by expression patterns from hormone metabolism genes. The establishment of anisocotyly is based on an imbalance between cytokinins and gibberellins, causing a shift from apical to lateral dominance that involves the suppression of the microcotyledon and groove meristem and promotion of the basal meristem. We point out future perspectives in the study of Streptocarpus organogenesis. Streptocarpus
\end{abstract}

Received: 10.02.2020; Revised \& Accepted: 23.03.2020

Published Online: 11.05 .2020 may provide a system to study the functional evolution of plant form in relation to adaptation to diverse environmental conditions.

Keywords: Basal meristem, Class I KNOX genes, Cytokinin, Gibberellin, Groove meristem, Plant growth form regulation.

\section{Introduction}

Members of the family Gesneriaceae exhibit a large diversity in shoot architecture (Weber, 2004), far greater that in any other plant family. Underlying this diversity, particularly found in the genus Streptocarpus Lindl., is the flexibility in the positioning and timing of meristem activity that appears almost randomly spread across the plant, but is in fact precisely placed and has very distinct functions (Burtt, 1970; Nishii et al., 2017). Streptocarpus is an African, Madagascar and Comoro Islands Gesneriad named after the uniquely twisted development of its fruits (Lindley, 1828; Hilliard \& Burtt, 1971). This is not the only unusual feature in this genus, but the plants also show major variation in their vegetative morphogenesis such as anisocotyly, phyllomorphic leaf development, unifoliate growth and leaf abscission zones (Burtt, 1963; Figs. 1, 2; Appendix 1).

In this review, we focus on the interactions of hormones in meristem formation and function involved in the unique vegetative morphogenesis in Streptocarpus. Specifically, we summarise the 

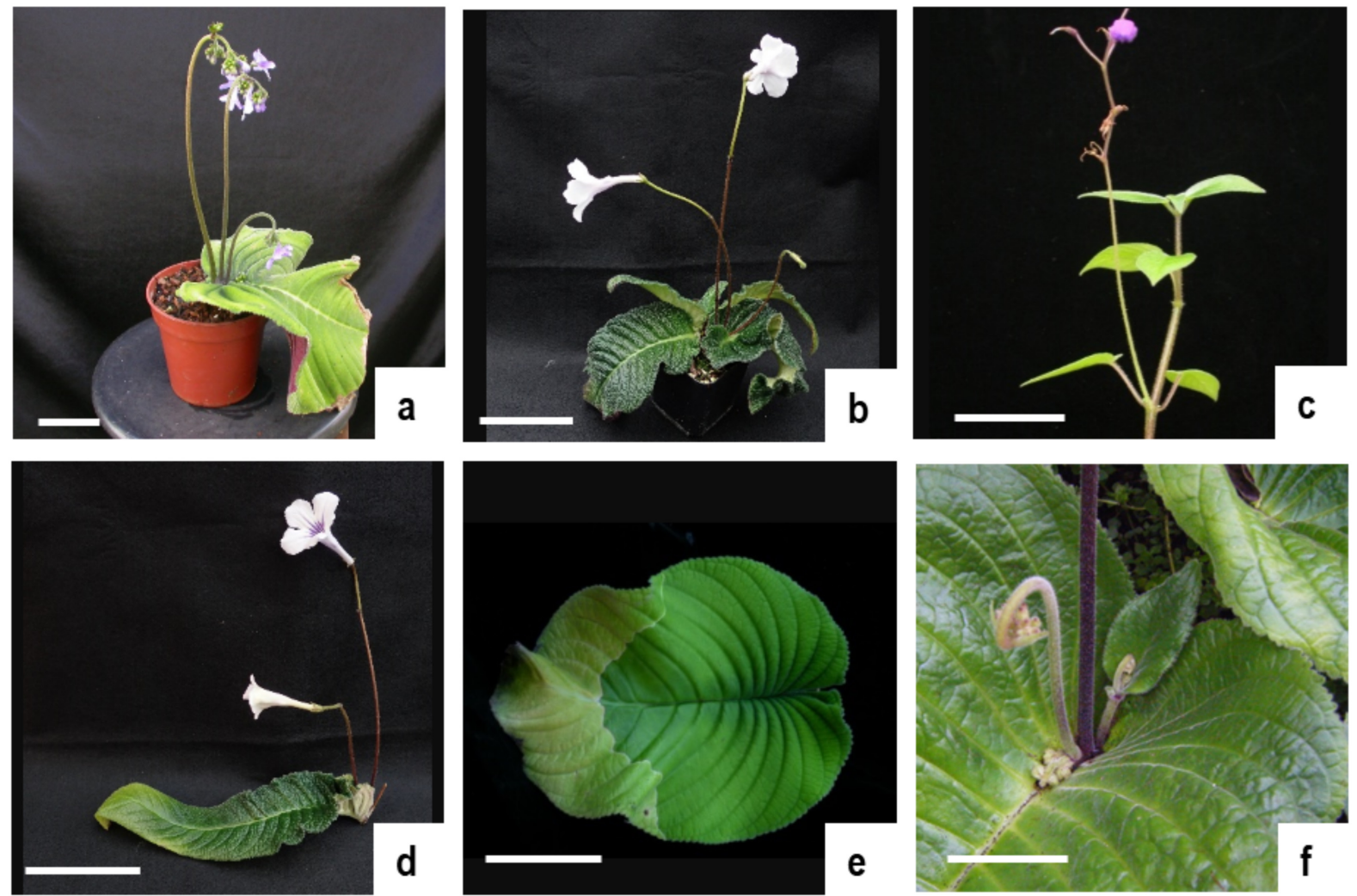

Fig. 1. Diverse morphologies and features present in Streptocarpus Lindl.: a. Unifoliate: $S$. wendlandii Spreng.; b. Rosulate: $S$. rexii (Bowie ex Hook.) Lindl. c. Caulescent: $S$. glandulosissimus Engl.; d. An excised flowering phyllomorph of the rosulate $S$. rexii resembling a unifoliate; e. Abscission zone formed in the lamina of $S$. wendlandii; $\mathbf{f}$. Subtending phyllomorph formed in front of the series of inflorescences at the proximal region of the lamina in the unifoliate $S$. wendlandii. Scale bars: $10 \mathrm{~cm}$ (from plants cultivated at the Royal Botanic Garden Edinburgh).

results from exogenous applications of plant hormones and their effects in the plant's development, and the putative roles of hormone metabolism genes. The regeneration from leaf explants is also included briefly here because it may shed light on the available physiological machinery in the organogenesis in Streptocarpus. Finally, we propose our current model of phyllomorph development and maintenance as governed by plant hormones, and an outlook on future studies.

Anisocotyly, the phyllomorph concept and growth forms in Streptocarpus

Anisocotyly, the uneven development of cotyledons has been reported since studies on Streptocarpus were published (Crocker in 1861[1860"]), which allows the seedling to acquire photosynthetic tissue rapidly (Burtt, 1970). As in other dicots, two cotyledons are formed during embryogenesis in Streptocarpus, and just after germination, both cotyledons grow equally. However, at around 10 days after germination, one cotyledon ceases its development while the other continues to grow (Fig. 2). This results in unequally-sized cotyledons, where the larger cotyledon is termed the macrocotyledon, and the smaller one the microcotyledon (Jong, 1970; Imaichi et al., 2000; Nishii et al., 2004). The direction and quality of light may be involved in the macrocotyledon determination (Saueregger \& Weber, 2004; Nishii et al., 2012b). Anisocotyly is a shared feature among Old World Gesneriaceae (i.e., subfamily Didymocarpoideae) with some exceptions (Huang et al., 2019). New World Gesneriaceae (i.e., subfamily Gesnerioideae), on the other hand, exhibit ordinary (equal) cotyledon development resulting in two microcotyledons (Burtt, 1963; Weber, 2004; Nishii et al., 2017).

In their monograph on Streptocarpus, Hilliard and Burtt (1971) described the significant variation in 

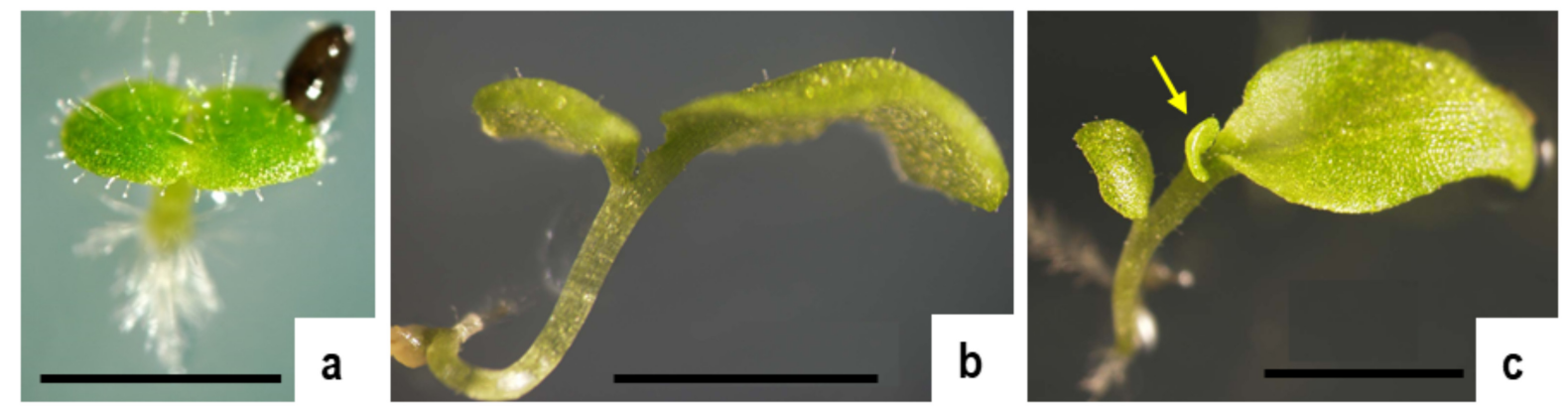

Fig. 2. Seedling development in Streptocarpus rexii (Bowie ex Hook.) Lindl.: a. Isocotylous seedling just after germination; b. Anisocotylous seedling; c. Anisocotylous seedling with additional phyllomorph formed from the proximal region of the macrocotyledon (arrow). Scale bars: $1 \mathrm{~mm}$.

the vegetative morphs in the genus, and roughly group these into caulescent species in subgenus Streptocarpella Fritsch bearing shoots with opposite simple leaves, and acaulescent in subgenus Streptocarpus forming a false rosette (rosulate) or remaining unifoliate (Fig. 1; Appendix I). Some acaulescent species are plurifoliate bearing only a few leaves throughout their lifetime. Phylogenetic studies on the evolution of the different morphologies show developmental plasticity that is reflected by repeated switches between the three basic growth forms (Möller \& Cronk, 2001).

Initially, it was attempted to compare the variations in the development of the diverse shoot architectures found in Streptocarpus with ordinary growth forms (Esau, 1977; Jong, 1970; Jong \& Burtt, 1975). However, some features did not fit the model. Of the three main morphs, caulescent, rosulate, and unifoliate, it was found that while caulescents retain an ordinary shoot with a central shoot apical meristem (SAM), the acaulescent, i.e., rosulates and unifoliates lacked a typical shoot and SAM (Jong, 1970). The leaf development of acaulescent Streptocarpus shows some further unusual features. In ordinary plants, such as Arabidopsis thaliana L. or Nicotiana tabacum L., and in caulescent Streptocarpus, the leaf consists of a lamina and a petiole, and the proximal end of the petiole is attached to the stem. The SAM is located at the shoot apex and leaf primordia are formed at the peripheral zone of the SAM. Moreover, a phytomer, a structural unit consisting of leaf and stem, is repeatedly formed from the SAM to form an ordinary shoot (Esau, 1977; Barthélémy \& Caraglio, 2007; Imaichi et al., 2007; Fig. 3). From his studies on acaulescent rosulate Streptocarpus, Jong (1970) concluded that the macrocotyledon and foliage leaf are "exceptional" in that they represent an integrated entity with characteristics of both shoot and leaf. In these Streptocarpus lacking a SAM, new leaves are initiated from primordia on an existing leaf. Therefore, he proposed the term phyllomorph for this foliar unit (Jong, 1970; Fig. 3).

To distinguish the developmental origin of phyllomorphs, the first is termed a cotyledonary phyllomorph and represents the developed macrocotyledon, while consecutively formed phyllomorphs are termed additional phyllomorphs (Jong, 1970). Thus, a rosulate possesses a cotyledonary phyllomorph and additional phyllomorphs, and both have similar abilities for bearing inflorescences (Fig. 1). Typical unifoliate species represent the most reduced form and possess only a cotyledonary phyllomorph but occasionally can bear an additional phyllomorph after inflorescence initiation: the subtending phyllomorph (Jong, 1970; Jong \& Burtt, 1975) or accessory phyllomorph (Jong, 1970), although Dubuc-Lebreux (1978) included those from de novo origin, rather than from a long-dormant groove meristem (see below) (Nishii et al., 2012a). Unlike other phyllomorphs, subtending phyllomorphs do not bear roots (Jong \& Burtt, 1975).

Each phyllomorph, starting with the cotyledonary phyllomorph, consists of a lamina and a petiole- 
stem unit termed a petiolode. Lateral adventitious roots are formed from the lower parts of the petiolode and each phyllomorph is monocarpic, i.e., dies after fruiting (Jong, 1970; Hilliard \& Burtt, 1971). The development from seedlings to mature plants in Streptocarpus is governed by several meristematic regions observed at the juxtaposition of the lamina and the petiolode. Three meristems work in synchrony: the basal meristem at the proximal region of the lamina is responsible for lamina expansion, the petiolode meristem for petiolode elongation and thickening, and the groove meristem located on the petiolode at the base of the lamina responsible for new organ initiation, such as the inflorescences and new phyllomorph primordia (Jong, 1970; Jong \& Burtt, 1975; Imaichi et al., 2000; Nishii \& Nagata, 2007) (Figs. 3, 4). The macrocotyledon in subgenus Streptocarpella has a basal meristem that sustains its enlargement for a short period of time only. It later shows characters of an ordinary leaf, with a lamina and petiole, and a shoot is formed from the SAM (Nishii et al., 2017). Phyllomorphs of species in subgenus Streptocarpus section Streptocarpus have evolved a further unique characteristic, the ability to form an abscission zone, a transverse abscission line on the lamina dividing it into a proximal and distal part that is cut off during unfavourable conditions (Hilliard \& Burtt, 1971; Noel \& Van Staden, 1975) (Fig. 1e).

\section{Molecular mechanisms of Streptocarpus meristems}

Many studies have been carried out over the last two decades to unravel the molecular mechanisms underlying phyllomorph formation and plant development in Streptocarpus. Since acaulescent Streptocarpus lack a SAM, it was hypothesized that mutations of meristem maintaining genes, such as those of the class 1 KNOX (KNOX1) homeobox gene family are involved (Cronk \& Möller, 1997; Tsukaya, 1997; Imaichi et al., 2000). In model plants KNOX1 genes maintain undifferentiated cells in the SAM, and the $A$. thaliana KNOX1 gene mutant shootmeristemless $(\mathrm{stm})$ lacks a SAM (Long et al., 1996; Hake et al., 2004). Studies on the expression of homologous STM1 genes in Streptocarpus show different patterns; while it was found in the SAM of the caulescent $S$. saxorum Engl., it was also expressed in the basal meristem and grove meristem of the rosulate Streptocarpus rexii (Bowie ex Hook.) Lindl. (Harrison, 2002; Harrison et al., 2005). The unifoliate Streptocarpus dunnii Hook.f. showed somewhat unstable expression patterns (Harrison 2002; Harrison et al., 2005), which might be linked to seasonal changes in growth activities since the
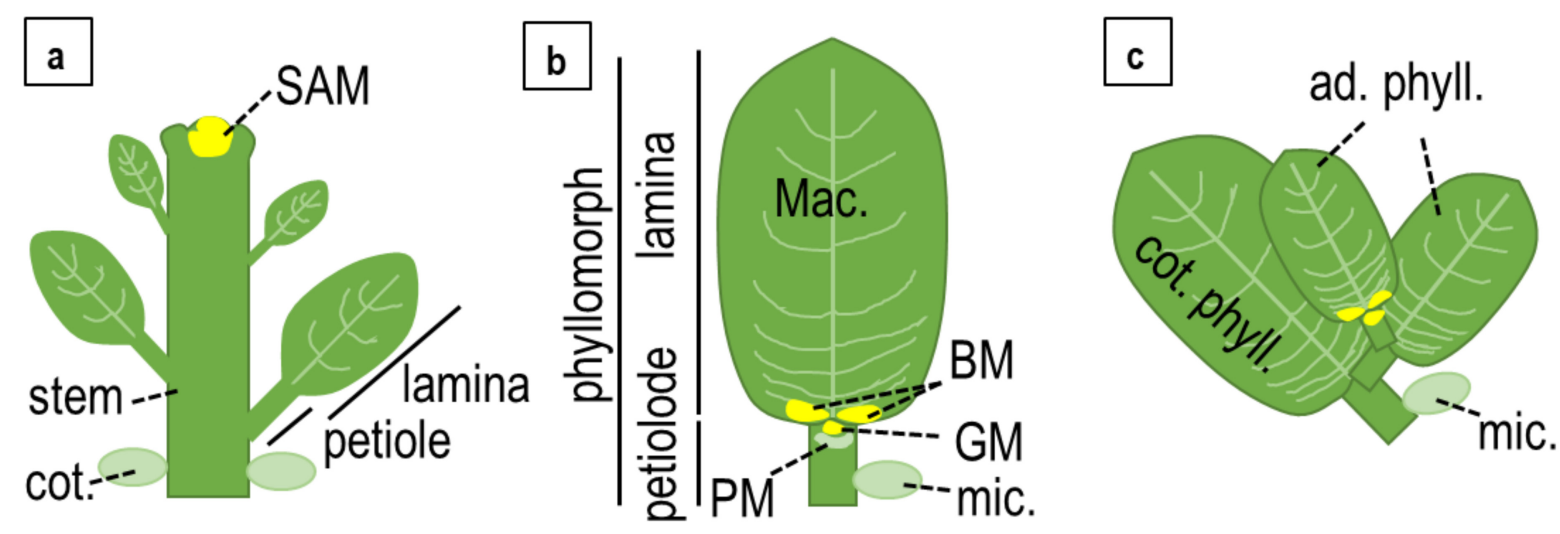

Fig. 3. Schematic illustration of an ordinary shoot (a) and acaulescent Streptocarpus Lindl. (b. unifoliate, c. rosulate). Meristem positions are highlighted in yellow. ad. phyll.: additional phyllomorph, BM: basal meristem, cot. phyll.: cotyledonary phyllomorph formed from the macrocotyledon, cot.: cotyledon, GM: groove meristem, Mac.: macrocotyledon, mic.: microcotyledon, PM: petiolode meristem, SAM: shoot apical meristem. 
plants require vernalisation (M. Möller, pers. obs.). STM1 expression is consistently found in the groove meristem and basal meristem in actively growing plants of another unifoliate Streptocarpus wendlandii Spreng. (Nishii et al., 2017).

Later on, the expression patterns of other developmental genes were investigated, mainly in the rosulate $S$. rexii that has become a model plant. To date, STM1 and BREVIPEDICELLUS (BP) from the KNOX1 gene family, WUSCHEL (WUS), ARP, and GRAMINIFOLIA (GRAM) from the $Y A B B Y$ gene family have been investigated (Harrison et al., 2005; Mantegazza et al., 2007, 2009; Nishii et al., 2010; Tononi et al., 2010; Fig. 5). Since these genes are well characterised and known to be the major players in the SAM and lateral organs formation and maintenance in model plants, they can be used to trace organs during Streptocarpus seedling development and in phyllomorphs as well. Early on in germination at the stage of cotyledon unfolding, the expression of the meristem marker gene STM1 is observed in the entire lamina of both cotyledons. Later, but still at the isocotylous stage, it is restricted to the proximal lamina region of both cotyledons. Soon after, STM1 expression disappears in the microcotyledon but remains in the basal meristem and in the groove meristem of the macrocotyledon. WUS has a role for maintaining the SAM in an undifferentiated state (Mayer et al., 1998; Schoof et al., 2000). WUS expression appears to be present in all three meristems of $S$. rexii phyllomorphs (Mantegazza et al., 2009) similar to STM1, although this ubiquitous expression might require further investigation. A MYB-like transcription factor, $A R P$ regulates the dorsoventrality of leaves and is expressed mutually exclusively with KNOX1 genes in leaf primordia in model plants (Waites et al., 1998; Byrne et al., 2000; Timmermans et al., 1999; Tsiantis et al., 1999). Unlike ordinary dicots with simple leaves, coexpression of $A R P$ and KNOX1-BP genes was observed in the simple-leaved Streptocarpus, in the basal and groove meristem in S. rexii, and the SAM of the caulescent Streptocarpus glandulosissimus Engl.
(Nishii et al., 2010). This co-expression in the SAM is similar to what is found in compound-leaved plants where KNOX1 genes regulate leaf meristematic activities required for forming leaflets along with ARP genes (Bharathan et al., 2002). These findings indicate a breakdown in Streptocarpus of the mutual exclusion of $A R P$ and $K N O X 1$ found in model plants with simple leaves. The different gene regulation might contribute to the ability of Streptocarpus to expand lamina from a basal meristem involving KNOX1. GRAM determines the abaxial fate of a leaf (Siegfried et al., 1999; Golz et al., 2004). GRAM is expressed on the abaxial side of $S$. rexii cotyledons similar to $A$. thaliana; and in the phyllomorph it is observed in the basal meristem but not in the groove meristem (Tononi et al., 2010). This indicates that GRAM retains a specific role in the basal meristem, possibly to determine the abaxial side of lamina while the leaf tissue is formed from the undifferentiated basal meristem.

These findings strongly support Jong's (1970) hypothesis for the developmental organisation of phyllomorphs as the equivalent of shoots and confirm their oddity. Indeed the phyllomorphs show meristem properties in the basal and groove meristem where functional meristem genes usually found in conventional SAMs are expressed. Their localization and interactions in the phyllomorph appear to have been modified during the evolution of the plants. Thus, one could argue functional equivalence between a SAM and at least the groove meristem, whereas the basal meristem has mixed properties of a SAM and a lateral organ (Fig. 5a, b). This may raise the question of whether acaulescent Streptocarpus are "hopeful monsters" (Theissen, 2006) by saltational evolution, or the product of step-wise shifts in meristem activity in space and time. Our study on the evolution of KNOX1 (STM1) expression patterns at least, does not follow the "hopeful monsters" route (Nishii et al., 2017). The most comprehensive survey of cotyledon development and KNOX1 expression across Gesneriaceae, to date reveals that the origin of cotyledonary basal meristems expressing KNOX1 

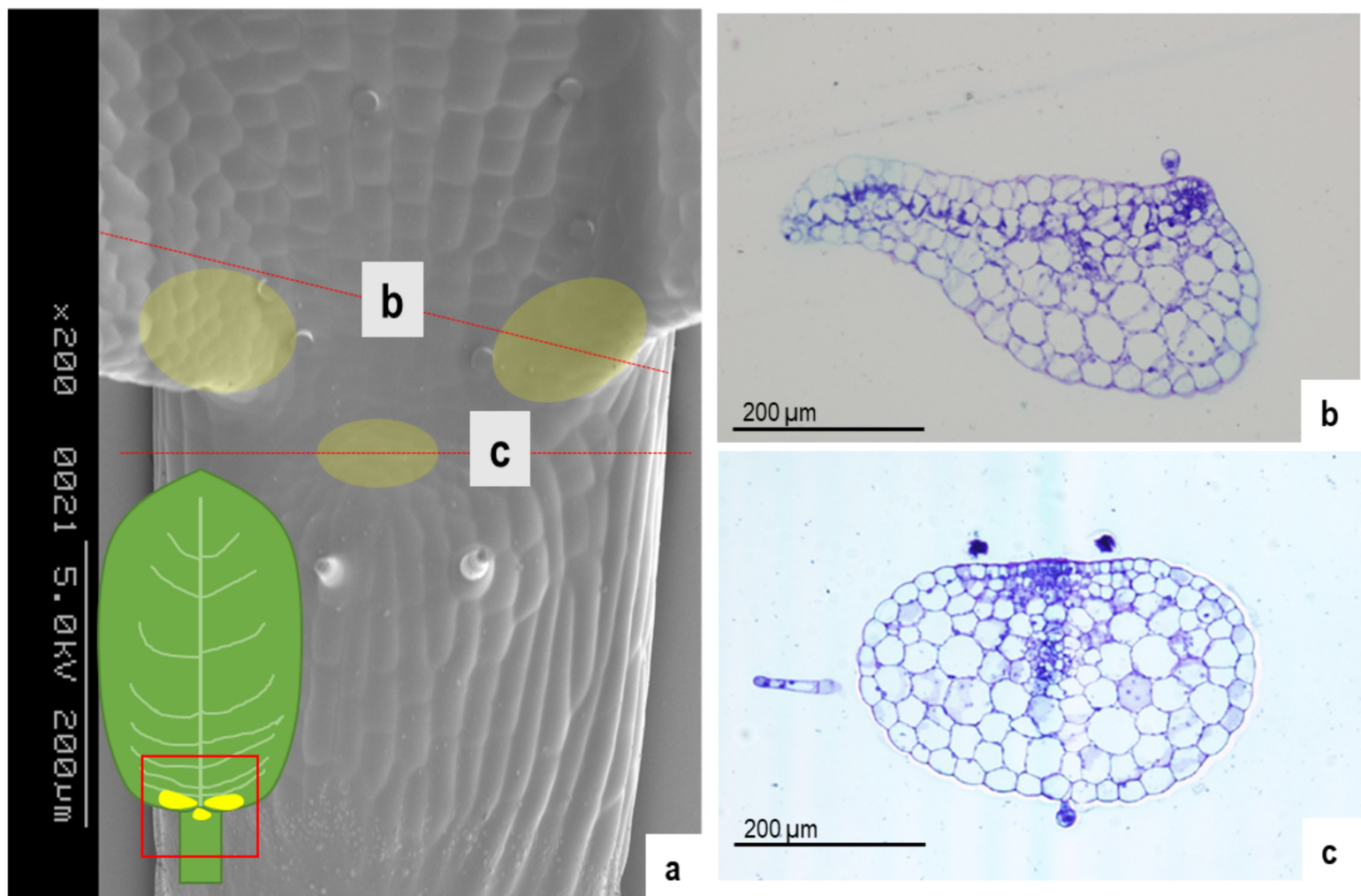

Fig. 4. Micrographs of meristems of a rosulate species of Streptocarpus Lindl.: a. Image of the junction between lamina of petiolode under the scanning electron microscope. Inset illustration indicates position in the phyllomorph. Dotted lines indicate the positions of sections in $\mathbf{b}$ and c of Toluidine blue stained Technovit mounted sections. b. Transverse section through the basal meristem; c. Transverse section through the groove meristem.

predates the age of Gesneriaceae as this feature already existed in other relatives of the Gesneriaceae: in the Lamiales, such as in Antirrhinum majus L. (Plantaginaceae) or Jovellana punctata Ruiz \& Pav. (Calceolariaceae) (Nishii et al., 2017). Apparently, in the family Gesneriaceae, the evolution of the extremely reduced unifoliate morphs culminated in the Old World lineage. The gradual modification of meristem activity is perhaps the basis for the major morphological diversity in the Streptocarpus (Nishii et al., 2017). It is likely that the physiological regulatory mechanisms, such as hormonal regulation, are involved in morphogenesis and play a role in the different Streptocarpus plant architectures.

\section{Timeline of plant hormone studies in Streptocarpus}

The earliest work on the effects of the exogenous application of plant hormones on shoot morphogenesis and leaf explant regeneration in Streptocarpus can be traced back to the 1970's. Dubuc-Lebreux and Vieth (Dubuc-Lebreux, 1976, 1978; Dubuc-Lebreux \& Vieth, 1975, 1976) reported on the effects of gibberellins (GA) and cytokinins (CK) on the development and regeneration of Streptocarpus plants. Appelgren and Heide (1972) comprehensively studied hormone effects on the regeneration from Streptocarpus leaf explants. Van Staden (1973) was the first to measure endogenous $\mathrm{CK}$ in relation to the formation of abscission zones. Rosenblum and Basile (1984) applied several plant hormones and reported their effects on seedling morphogenesis. Nishii et al. (2004, 2012a) examined the effects of exogenous application of CK and GA on unifoliate Streptocarpus. Recent studies on the acaulescent rosulate $S$. rexii shed light on the interaction between exogenous CK and GA, and their metabolic genes, and interactions between 
exogenous hormones and meristem genes (Mantegazza et al., 2007, 2009; Nishii et al., 2014; Chen et al., 2017). While most of the studies focused on GA and CK, other hormones, such as auxins and abscisic acid have also been investigated (Appelgren \& Heide, 1972; Rosenblum \& Basile, 1984; Nishii et al., 2004).

\section{Exogenous application of GA in Streptocarpus}

GA regulates the induction of flowering and germination in plants, and has important roles for many other aspects in plant growth (Yamaguchi, 2008), including hypocotyl and stem elongation and leaf enlargement (Cowling \& Harberd, 1999; Alabadí et al., 2008; Sun, 2010). In the SAM, GA promotes differentiation of organ primordia (Jasinski et al., 2005).

Several studies report on the effects of exogenous GA applications to seedlings or young Streptocarpus plants. The results indicate a complex role of the hormone in several developmental aspects including elongated hypocotyls and petiolodes in S. wendlandii seedlings through the expansion in cell length rather than cell division (Nishii et al., 2012a). GA application to 9-14 months old S. wendlandii plants also induced an elongated petiolode and a narrower lamina, though the author did not carriy out microscopic observations (Dubuc-Lebreux, 1976). Thus, GA appears to induce organ etiolation through cell elongation in Streptocarpus similar to ordinary plants (Alabadí et al., 2008).

Exogenous GA application also has drastic effects on the activity of meristems in Streptocarpus. In seedlings, it inhibits the basal meristem of the macrocotyledon which results in the formation of two microcotyledons in the unifoliate $S$. wendlandii (Nishii et al., 2012a), the plurifoliate S. prolixus C.B.Clarke (Rosenblum \& Basile, 1984), and the rosulate S. rexii (Nishii et al., 2014; Mantegazza et al., 2009; Figs. 6, 7). Thus, this response seems to be common in Streptocarpus, irrespective of the mode of GA application (soil drench or incorporation into the growing medium).
While exogenously applied GA suppresses the basal meristem activity, it simultaneously promotes the activity of the groove meristem. In one of the earlier hormone experiments, it was reported that exogenous GA application to seedlings induces a "caulescent form", by developing "shoots" in the acaulescent plurifoliate S. prolixus (Rosenblum \& Basile, 1984). A similar morphology was observed in GA treated rosulate $S$. rexii seedlings. The treated plants did not show enlarged lamina but formed additional phyllomorphs with elongated petiolodes much earlier than control seedling giving the appearance of a shoot (Nishii et al., 2014). Thus, the "shoot" reported by Rosenblum and Basile (1984) represents a tandemly arranged assemblage of phyllomorphs with etiolated petiolodes. Surprisingly also in S. wendlandii, a unifoliate species that does not bear additional phyllomorphs, exogenous GA induced the formation of an additional phyllomorph from the groove meristem that is usually perpetually dormant in unifoliates (Imaichi et al., 2000; Nishii et al., 2012a) (Fig. 6d). In turn the additional phyllomorph develops into an ordinary phyllomorph bearing inflorescences (K. Nishii, pers. obs.). Exogenous GA treatments of unifoliate species such as Streptocarpus michelmorei B.L.Burtt and S. wendlandii $61 / 2$ to 14 months old showed an increase in additional phyllomorphs originating from the groove meristem (i.e., subtending phyllomorphs). Moreover, adventitious phyllomorphs arose de novo on the petiolode (Dubuc-Lebreux, 1976, 1978). Additionally, the subtending phyllomorph showed an increase in additional phyllomorphs similar to the "false shoot" in GA-treated seedlings. Thus, GA appears to negatively regulate the dormancy of the groove meristem and positively regulates the phyllomorph initiation from the groove meristem in Streptocarpus.

The opposing effects of GA on the basal meristem and groove meristem allow the hypothesis of an antagonistic balance in a phyllomorph between lamina expansion and new phyllomorph initiation. The most extreme form appears in unifoliate Streptocarpus, where the basal meristem is active 
from germination onwards until the inflorescence meristem starts developing (Nishii et al., 2017). During this time, the groove meristem stays morphologically and developmentally dormant (Jong, 1970; Imaichi et al., 2000). In rosulate S. rexii, the basal meristem is active for a while but it ceases earlier than in unifoliates, and the meristem balance shifts earlier to the groove meristem to initiate new phyllomorphs before inflorescences are initiated (Nishii et al., 2017). Therefore, the basal meristem activity in unifoliate is stronger or more persistent than that in rosulates, and suppresses new phyllomorphs from the groove meristem, and GA may be involved in this pathway (Nishii et al., 2012a, 2014)(Figs. 5-7). This phenomenon has been described as "lateral dominance" as opposed to "apical dominance" in ordinary shoots, where the apical shoot suppresses the development of lateral shoot growth (Tsukaya, 1997; Nishii et al., 2012a). Considering the role of GA in an ordinary SAM, GA may promote phyllomorph differentiation from the groove meristem. In other words, the groove meristem stays undifferentiated while the existing lamina is expanding, but once the basal meristem activity ceases and GA is upregulated, or vice-versa, the dormancy of the groove meristem is broken to form new phyllomorphs, although further studies are needed before conclusive statements can be made here.

\section{Localization of GA metabolism genes in Streptocarpus}

In model plants, high concentrations of endogenous GA are observed in differentiated leaf primordia that promote cell differentiation (Jasinski et al., 2005). The localization of GA in the SAM is finely controlled by its metabolic genes: the GA synthesis gene GA20-oxidase is found in leaf primordia and the GA degrading gene GA2-oxidase is localized at the base of the SAM that prevents the accumulation of GA in the SAM (Jasinski et al., 2005; Bolduc \& Hake, 2009) (Fig. 5d).

In $S$. rexii, SrGA20-oxidase is expressed in the lamina whereas $\mathrm{SrGA2-oxidase}$ is found in the basal meristem and in the groove meristem (Nishii et al.,
2014) (Fig. 5c). Thus, the expression domain for

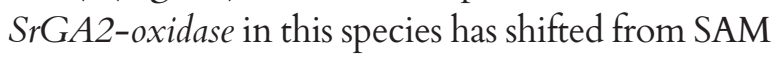
to lamina and thus differs from the model plant pattern, even if it retains the same role of meristem maintenance. SrGA2-oxidase may prevent GA incorporation in the Streptocarpus phyllomorph meristems and maintains cells in an undifferentiated state. On the other hand, and similar to model plants, SrGA20-oxidase is found expressed in the differentiated lamina in Streptocarpus. Thus, GA may also be required for cell differentiation and growth of lamina tissue in Streptocarpus. Intriguingly, during embryogenesis, SrGA20-oxidase is expressed between the cotyledons where ordinary plants form the embryonic SAM. This suggests that GA might be involved in the absence of an embryonic shoot apical meristem in Streptocarpus (Nishii et al., 2014). Thus, GA appears to be a negative regulator of the SAM in A. thaliana or phyllomorph meristems in Streptocarpus, but the expression patterns of the GA metabolism genes have shifted, matching their meristem locations.

\section{Exogenous CK promote basal meristem activity in Streptocarpus}

Cytokinins have important roles for maintaining the SAM, and for cell division and growth of plants (Osugi \& Sakakibara, 2015). During the regeneration from leaf explants, $\mathrm{CK}$ is known to induce shoot regeneration by interacting with auxin, and also prevents senescence (Gan \& Amasino, 1996; Su et al., 2011).

In Streptocarpus, during the early stages of germination the basal meristem in the microcotyledon appears to be affected most by exogenous CK. Rosenblum and Basile (1984) were the first to report that CK treatment induced "twin phyllomorph" in the plurifoliate S. prolixus as well as unifoliate $S$. grandis N.E.Br., S. solenanthus Mansf., S. erubescens Hilliard \& B.L.Burtt and the caulescents S. nobilis C.B.Clarke and S. muscosus C.B.Clarke (Figs. 6, 7). This finding has been corroborated for the unifoliate $S$. wendlandii where seedlings grown on medium containing CK, or sprayed with CK when growing in compost show meristem activity 
in both cotyledons and induced the formation of two macrocotyledons (Nishii et al., 2004; K. Nishii \& M. Möller, pers. obs.). Moreover, this effect confirms that in Streptocarpus, during the early stages of germination, both cotyledons have basal meristem activity (Nishii \& Nagata, 2007). The effect of CK to induce twin macrocotyledons is time limited since once anisocotyly is established the microcotyledon has lost its ability to resume growth (Nishii et al., 2004). This suggests that at the isocotylous stage, as long as the basal meristem is active, it is perceptive to exogenous CK to trigger persistent basal meristem activity in both cotyledons, but once the fate of the microcotyledon is determined and the basal meristem activity ceases it is no longer perceptive to CK.

Once two macrocotyledons are established by exogenous CK, both cotyledonary phyllomorphs grow to maturity, and each bears a separate series of inflorescences and subtending phyllomorph (Rosenblum \& Basile, 1984) (Fig. 6e, f). In older S. wendlandii CK treatment causes only a slight reduction in the formation of subtending phyllomorphs (Dubuc-Lebreux, 1978). This may indicate some effect of CK suppressing the phyllomorph initiation from a usually dormant groove meristem, although the reported effect is small. Rosulate $S$. rexii also develop two macrocotyledons after CK application (Mantegazza et al., 2009).

Not much is known about endogenous CK in Streptocarpus. One study reports the distribution of $\mathrm{CK}$ in relation to senescence and another the interaction with the phyllomorph meristems (Van Staden, 1973; Chen et al., 2017). In the unifoliate Streptocarpus molweniensis Hilliard, the proximal and distal lamina area retain similar levels of cytokinins during early summer. However, these decrease towards the autumn in the distal region of the lamina and may be linked to the formation of an abscission zone (Van Staden, 1973). This shift in distribution towards the end of the growing season might be a pre-requisite and together with the slope of CK gradient, may determine the position of the abscission line on a phyllomorph. This intentional reduction in leaf area is a quite different mechanism compared to ordinary plants in which CK play a role in the prevention of senescence and maintenance of chlorophyll in the lamina (Alberte \& Naylor, 1975; Gan \& Amasino, 1996), and might best be compared with leaf abscission in which CK is involved in (Xu et al., 2019).

With a view to meristem formation, it is expected that the proximal region of a macrocotyledon or phyllomorph might show higher CK concentrations. However, in the seedling stage of $S$. rexii, the CK concentration is very similar in the proximal and distal region of the macrocotyledon, and the microcotyledon. Only isopentenyladenosine (iPR) shows a slightly higher concentration in the proximal part of the macrocotyledon (Chen et al., 2017). It is still possible that the CK localization in the meristematic area of young seedlings was missed because it is very small. Immune-histological methods with CK antibodies might be useful to pinpoint the CK distribution in Streptocarpus meristem (e.g., Dewitte et al., 1999).

\section{Redundancies and distinctive roles in the IPT gene family in Streptocarpus}

The cytokinin biosynthesis gene family isopentenyltransferase (IPT) includes genes with redundancies but also with differentiation of functions (Miyawaki et al., 2006; Nishii et al., 2018). In $A$. thaliana, nine IPTs are reported, and among these, AtIPT7 is upregulated by the KNOX1 gene $S T M$ in the SAM and produces CK (Jasinski et al., 2005; Yanai et al., 2005). CK, in turn, upregulates $S T M$ in the SAM. In S. rexii, five IPT genes are known to date, of which two, adenosine phosphateIPT SrIPT5 and tRNA-IPT SrIPT9, are expressed in the vegetative tissue as well as in floral tissues and roots (Chen et al., 2017). Their homologs in A. thaliana are AtIPT5, expressed in roots and rosette leaves, and AtIPT9 is found ubiquitously in the whole plant (Miyawaki et al., 2004). Other IPTs seemed to have acquired specific roles for flower (SrIPT1) or root (SrIPT3) formation (Chen et al., 
2017) (Fig. 5). Of SrIPT5 and SrIPT9, the former in particular shows a strong expression in the groove meristem, and is highly expressed in the proximal part of the lamina. On the other hand, SrIPT9, while expressed ubiquitously in the lamina, shows higher expression in the distal part. Both, SrIPT5 and SrIPT9 are found in the groove meristem, but have acquired different responses to exogenous hormones: auxin suppresses the expression of both SrIPT5 and SrIPT9, but GA only suppresses SrIPT9 (Chen et al., 2017). Exogenous application of CK does not alter the expression of SrIPTs, which might support the notion of sufficient endogenous CK levels in the phyllomorph for its functioning. Therefore, CK itself seems not to control CK biosynthesis, but is maybe regulated by other hormones such as auxin or GA.

The expression of IPTs is not exclusive to the distal lamina part, which is consistent with endogenous cytokinin distributions (Van Staden, 1973; Chen et al., 2017) (Fig. 5). The expression of SrIPT9 in particular, was even higher in the distal than the proximal part in a mature lamina. SrIPT9 is a tRNA-IPT, and two tRNA-IPTs, AtIPT2, AtIPT9, exist in $A$. thaliana. Single mutants of those genes do not show clear phenotypes in $A$. thaliana, but the double mutant atipt 29 shows chlorotic effects (Miyawaki et al., 2006). In Streptocarpus, exogenous GA applications induce chlorotic effects (Nishii et al., 2014), and also downregulate SrIPT9 (Chen et al., 2017). Thus, it can be speculated that SrIPT9 has some role in the maintenance of chlorophyll in the lamina.

\section{Effects of other hormones on meristem activity in Streptocarpus}

There are only a few studies available on hormone effects other than CK and GA in Streptocarpus. Auxin is one of the major plant hormones involved in various aspects of plant development including shoot formation (e.g., Barton, 2010; Leyser, 2018 (Fig. 5). However, the role of auxin in Streptocarpus development is very poorly understood. External application has no clear effect on seedling development in the plurifoliate $S$. prolixus, whereas a treatment with 2,3,5-triiodobenzoic acid (TIBA), a polar auxin transport inhibitor, suppresses cotyledon expansion and induces a "shoot" (i.e., additional phyllomorphs) similar to GA (Rosenblum \& Basile, 1984) (Fig. 7). Exogenous auxins suppress SrIPTs, and thus it might be involved in controlling the internal CK levels (Chen et al., 2017) (Fig. 5) and the regulation of growth in Streptocarpus, possibly including anisocotyly. This can be supported by findings that the distribution of auxin affects the symmetric growth of the lamina in tomato and A. thaliana (Chitwood et al., 2012). It would be interesting to examine the relationship between auxin transport and the regulation of meristems in Streptocarpus.

Some effects of abscisic acid (ABA) on Streptocarpus seedling development have been reported. ABA inhibits growth, but causes no drastic change in shoot architecture (Rosenblum \& Basile, 1984). Similar results are reported in Nishii et al. (2004), where ABA application inhibits the cotyledon growth and reduced anisocotyly. These mild effects on anisocotyly and phyllomorph development suggest that ABA only plays a marginal role in Streptocarpus ontogeny.

\section{Hormonal effects on the regeneration in Streptocarpus}

In many plants, the application of auxin and CK induces regeneration from leaf explants and their balance of concentrations regulates regeneration. In general, a high auxin ratio induces the pluripotency of cells, callus, or root regeneration, and a high CK ratio induces shoot regeneration (Ikeuchi et al., 2016). While $A$. thaliana requires hormonal application for shoot regeneration, Streptocarpus leaf explants can form de novo shoots and roots without hormone supplementation (Dubuc-Lebreux \& Vieth, 1975; Chaudhury et al., 2010). The histological processes of shoot regeneration studied in some species of Streptocarpus section Saintpaulia (H.Wendl.) Mich.Möller \& Haston confirms the direct initiation of shoots (Naylor \& Johnson, 1937; Lo et al., 1997). 
Intriguingly, the ratio of regenerating leaf explants to non-regenerating leaf explants strongly depends on the auxin concentration in the culture media, while the concentration of CK has very little effect (Appelgren \& Heide, 1972), although the number of buds per explant is greatly increased with the addition of CK (Chaudhury et al., 2010). It may be that the lamina of Streptocarpus retains sufficient levels of CK to invoke shoot regeneration (Appelgren \& Heide, 1972). However, it seems that the CK concentration in Streptocarpus is not high compared to that in A. thaliana, although it is difficult to compare interspecifically from different studies (Kiba et al., 2013; Chen et al., 2017). In A. thaliana, CK downstream B-type ARR transcription factors regulate $W U S$ that in turn initiate shoot regeneration (Zhang et al., 2017). Thus, it is possible that genes downstream to CK genes, could be constitutively expressed in Streptocarpus, which would contribute to the high regeneration ability in Streptocarpus.

GA application inhibits the shoot bud regeneration from callus in A. thaliana (Ezura \& Harberd, 1995). There are only a few and conflicting results reported of GA effects on the regeneration from leaf explant in Streptocarpus. Dubuc-Lebreux and Vieth (1975) reported positive GA effects such as accelerated bud initiation from leaf explants in S. wendlandii, but without statistical analyses. On the other hand, exogenous GA negatively affects the regeneration from Streptocarpus leaf explant, i.e., reduced regeneration rate, and number of buds or roots, in S. x hybridus 'Constant Nymph' and S. prolixus, with statistical support (Appelgren \& Heide, 1972; Rosenblum \& Basile, 1984). Such negative effects are also reported in A. thaliana (Ezura \& Harberd, 1995), and Solanum lycopersicum L. (LombardiCrestana et al., 2012). In Streptocarpus, ABA also promotes the regeneration from leaf explant in conjunction with an optimal auxin concentration (Appelgren \& Heide, 1972).

The Streptocarpus lamina seems to represent a modified physiological entity compared to leaves in ordinary model plants and the tissue responds positively to, but is not depending on, exogenous hormones during regeneration. Understanding the CK signal transduction cascades in Streptocarpus might be the key to understand the high regenerative ability in Streptocarpus.

\section{Hypothesis of hormone - developmental gene crosstalk in Streptocarpus meristems}

The SAM is an organized structure with specific zones playing different roles in shoot development. The expression of genes and hormone distributions involved in this process are carefully controlled by cis and trans acting networks. In the SAM, GA and CK interact via KNOX1 genes: KNOX1 genes suppress GA but promote CK biosynthesis. In the model plant $A$. thaliana, endogenous GA degradation increases the expression of KNOX1 genes (Singh et al., 2010). On the other hand, exogenous CK treatment induces an increase in KNOX1 gene expression (Rupp et al., 1999), and KNOX1 genes positively regulate $\mathrm{CK}$ synthesis via IPT genes. CK treatments also partially recover KNOX1 mutant phenotypes (Jasinski et al., 2005; Yanai et al., 2005). For auxins, polar transport creates physical auxin maxima in locations of incipient leaf primordia initiation in the peripheral zone of the SAM where KNOX1 is downregulated (e.g., Hay \& Tsiantis, 2010; Singh et al., 2010) (Fig. 5).

Meristems in Streptocarpus phyllomorphs, particularly the groove meristem, retain similar characteristics to a SAM (Fig. 5). This is shown for GA and CK through expression studies of their metabolic genes (see above). Similar to the SAM, the antagonistic roles of GA and CK via KNOX1 genes are preserved in the meristems of Streptocarpus (Mantegazza et al., 2009; Nishii et al., 2014; Chen et al., 2017) (Fig. 5). Therefore, in Streptocarpus, the molecular and physiological units consisting of shoot and SAM function still exist, but have been transferred to the lateral organ, the phyllomorph. Consequently, the expression patterns of meristem genes and related factors are modified for establishing the plant's unique architecture. 

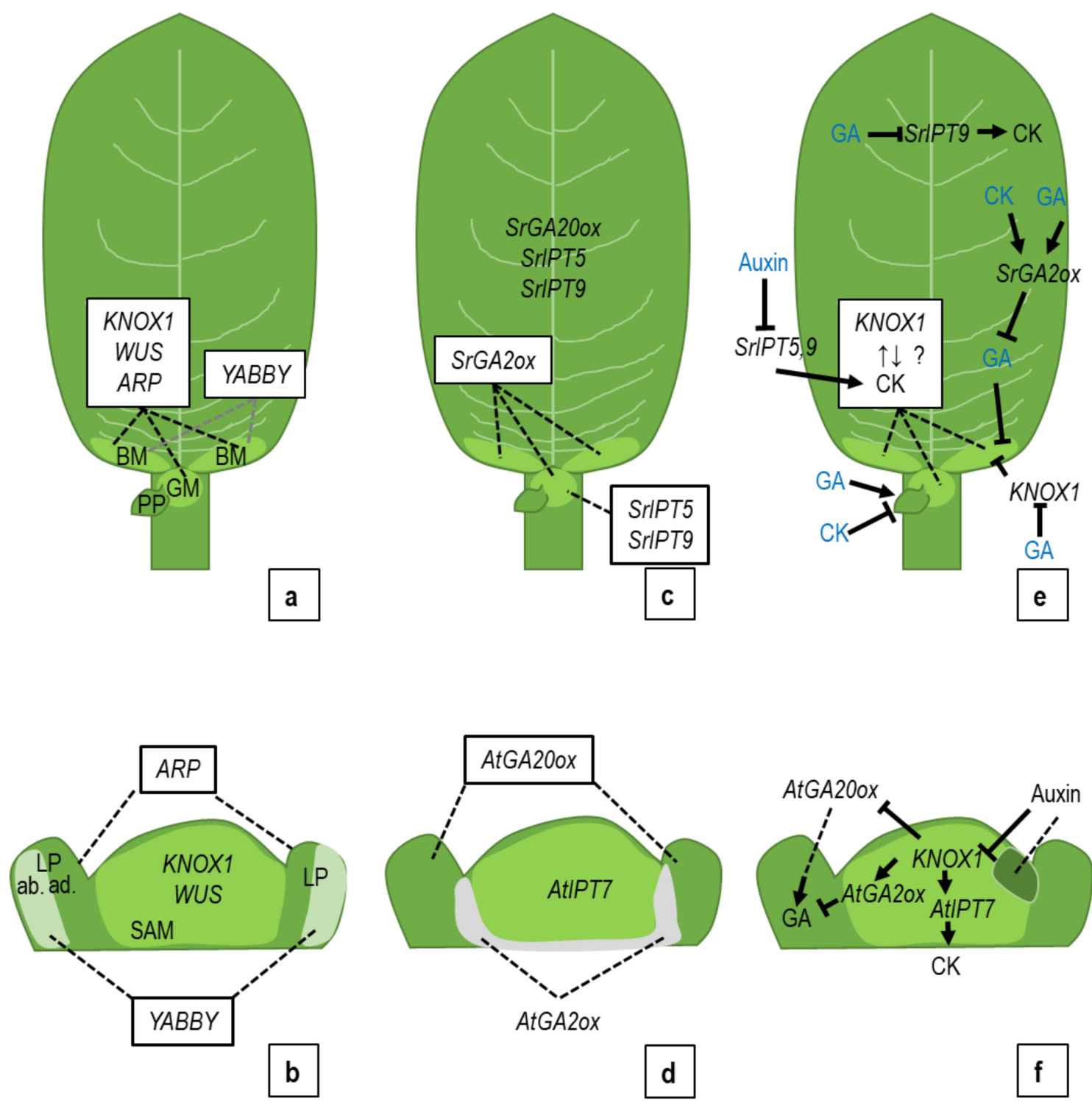

Fig. 5. Schematic summaries of currently reported genetic pathways in the phyllomorph of acaulescent rosulate Streptocarpus Lindl. (upper row) and the SAM of the model plant Arabidopsis thaliana L. (lower row): a \& b. Expression patterns of developmental genes. For details and background see also Mantegazza et al. (2007, 2009), Nishii et al. (2010), and Tononi et al. (2010). c \& d. Expression patterns of GA and CK metabolism genes in S. rexii (Bowie ex Hook.) Lindl. (SI) and A. thaliana (At). GA20-oxidase (GA20ox) synthesizes and GA2-oxidase (GA20x) degrades GA. Isopentenyltransferase (IPT) synthesizes CK. e \& f. Current model of hormone-gene interactions in Streptocarpus and in $A$. thaliana. In A. thaliana, KNOX1 induces AtIPT7 and AtGA20x expression, whereas it suppresses AtGA20ox, which is usually expressed in the leaf primordia. Auxin transporters create auxin maxima in the position of incipient leaf primordia and suppress KNOX1 expression (e.g., Barton, 2010; Hay \& Tsiantis, 2010). In Streptocarpus, KNOX1 expression is observed in the basal meristem and groove meristem (Mantegazza et al., 2007). Hormone applications in seedlings suggest that CK may maintain basal meristem activity with KNOX1 expression, whereas GA may suppress basal meristem and KNOX1 (Nishii et al., 2004, 2012a; Mantegazza et al., 2009). Exogenous GA promotes the initiation of phyllomorph primordia from the groove meristem, whereas exogenous CK suppresses it (e.g., Dubuc-Lebreux, 1978; Rosenblum \& Basile, 1984). Either exogenous CK or GA upregulate SrGA2-oxidase, reducing GA levels (Nishii et al., 2014). Auxin application suppresses both, SrIPT5 and SrIPT9, while exogenous GA only suppresses SrIPT9 (Chen et al., 2017). Lettering in black in $\mathbf{e}$ and $\mathbf{f}$ is based on evidence from endo- and exogenous hormone studies, and in blue only on exogenous hormone application experiments. ab.: abaxial, and ad.: adaxial leaf surfaces, BM: basal meristem, GM: groove meristem, LP: leaf primordium, PP: phyllomorph primordium, SAM: shoot apical meristem. 

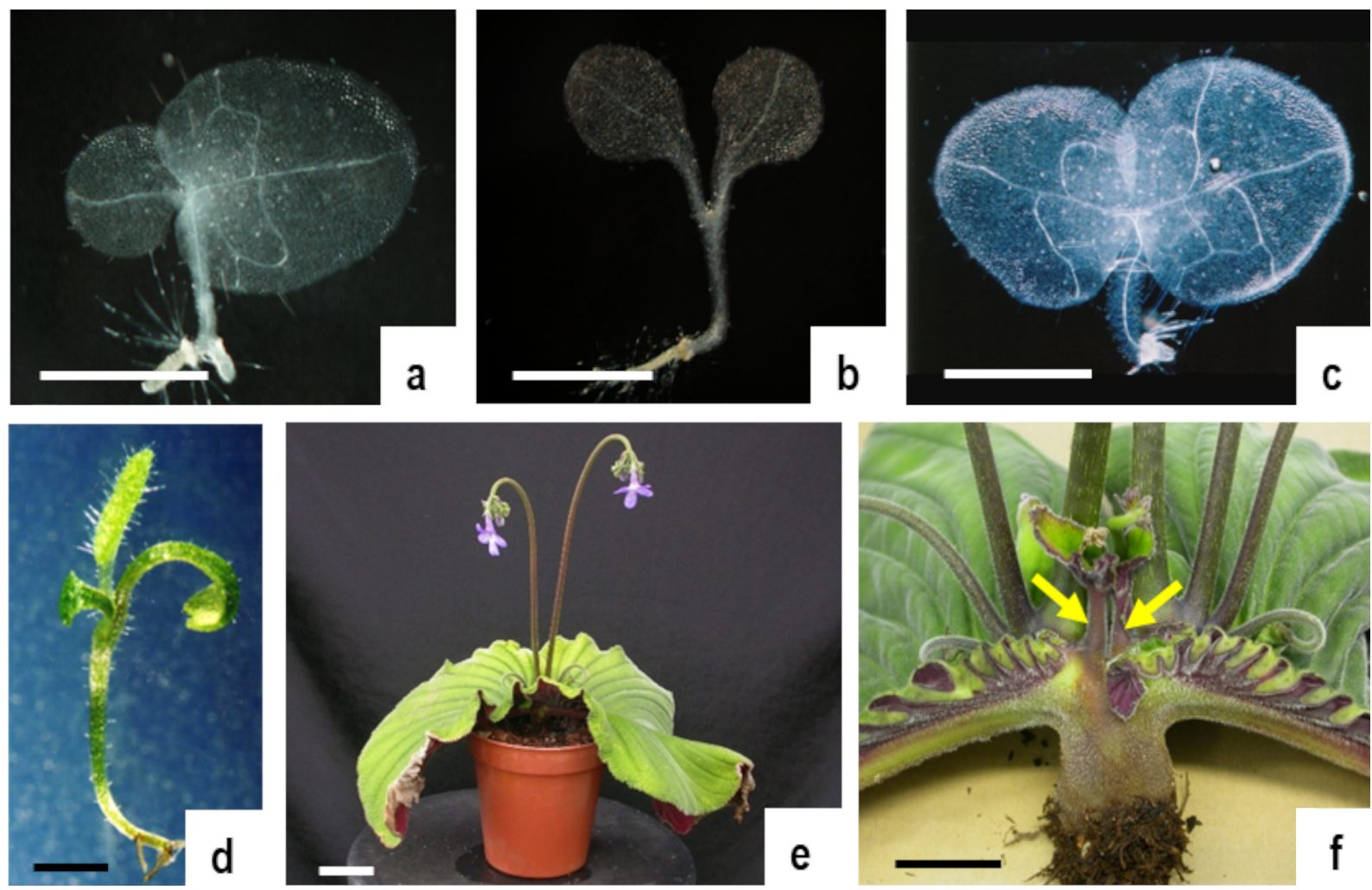

Fig. 6. Effects of exogenous hormone applications on unifoliate Streptocarpus wendlandii Spreng.: a-c. Seedlings 30 days after sowing. a. Control seedling showing anisocotyly. b. GA treated seedling showing two microcotyledons and elongated petiolodes. c. Benzylaminopurine (BAP; CK) treated seedling showing two macrocotyledons. d. GA treated seedling 45 days after sowing, showing an additional phyllomorph between the two microcotyledons. e \& f. BAP treated $S$. wendlandii seedlings at flowering. e. Whole plant with two cotyledonary phyllomorphs developed from two macrocotyledons. f. Longitudinally dissected plant showing that each cotyledonary phyllomorph individually retains an acropetal series of inflorescences and each develops a subtending phyllomorph (arrows). Scale bars: $1 \mathrm{~mm}$ (a-d), $5 \mathrm{~cm}$ (e \& f).

In Streptocarpus seedlings, the external application of CK promotes lateral growth whereas GA induces apical growth. This is accompanied by the expression of $K N O X 1$ in the basal meristems. While CK promotes KNOX1 in cotyledons, KNOX1 expression is suppressed there in the rosulate $S$. rexii after GA treatment (Mantegazza et al., 2009) (Fig. 5). Thus, GA might be responsible for the inhibition of the basal meristem activity through downregulating KNOX1. This might be important in the establishment of anisocotyly by suppressing the basal meristem of the microcotyledon (Figs. 57). GA interacts with environmental signals, such as light (Alabadí et al., 2008), and in Streptocarpus may regulate the balance between lamina expansion and phyllomorph initiation to suit the environment. GA may promote the organ differentiation from the undifferentiated groove meristem, and thus it induces apical growth in the form of additional phyllomorphs. Thus it seems that Streptocarpus possesses regulatory units involving GA, CK via KNOX1, similar to ordinary shoots, but it appears that at least in acaulescents an apical dominance model is amended by a lateral dominance model through the relocation of meristems from the shoot apex to lateral organ, or completely replaced as in unifoliates.

\section{Future perspectives}

The vegetative organogenesis of Streptocarpus has unique features. The underlying developmental mechanisms become slowly understood. However, there are still many challenges to reveal the entire network of interactions between growth forms and genes. The effects of the plant hormones GA and CK on Streptocarpus seedlings have long been known and the recent expression studies on their metabolic genes and meristem genes have shed 


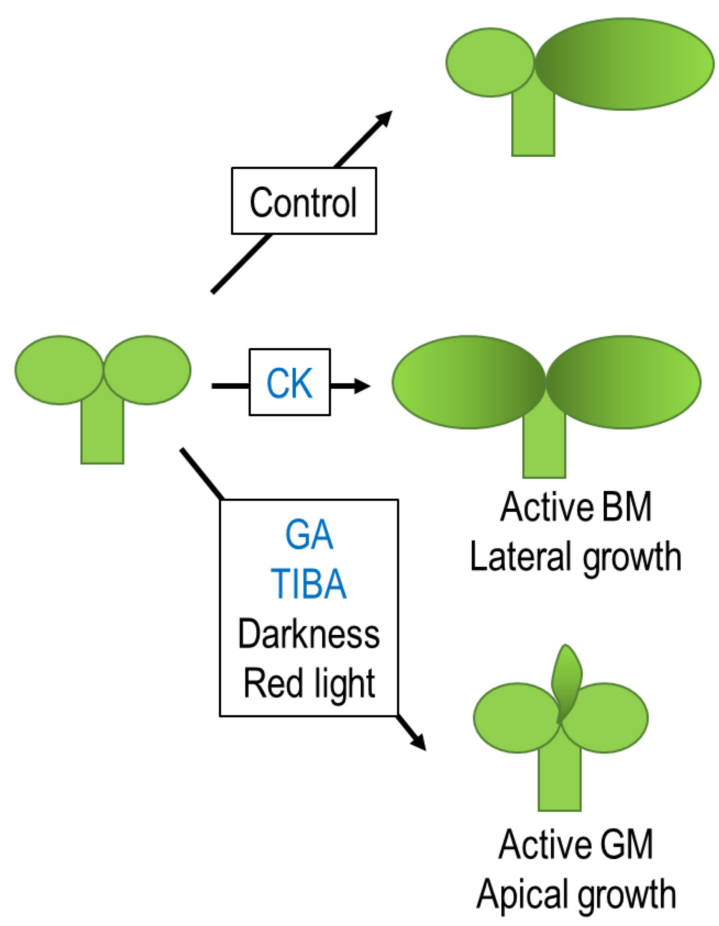

Fig. 7. Schematic illustration of the developmental pathways of Streptocarpus Lindl. seedlings as affected by hormones and environmental cues. Exogenous CK induces two macrocotyledons with active basal meristems (lateral growth), whereas exogenous GA and the auxin transport inhibitors (TIBA), darkness, or red light treatments induced two microcotyledons with accelerated phyllomorph initiation (apical growth).

some light on the molecular mechanisms involved in the establishment of anisocotyly and the growth of the unique leafy unit 'phyllomorph'. The role of other plant hormones, particularly auxin, requires to be investigated to understand its involvement in Streptocarpus development. Further, most studies were limited to the exogenous application of hormones, but to understand their physiological role more details are needed about the endogenous status of plant hormones. Some environmental factors may also have close links to the hormonal regulation in Streptocarpus and these have been very much neglected, particularly with view to the establishment of anisocotyly. There is only one study investigating light where it is shown that the direction of light seems to determine the fate of the macrocotyledon (Saueregger \& Weber, 2004). Studies of light signal transduction in Streptocarpus are needed to elucidate the first steps in the establishment of a hormone imbalance that seems to be the basis for the unequal development of the cotyledons. The petiolode meristem has likewise received little attention, although its development differs greatly between caulescent and acaulescent Streptocarpus species.

The published research regarding the molecular mechanisms of Streptocarpus development mainly relies on expression studies of genes characterised in model plants. However, these studies are limited since it is often overlooked that model plants such as $A$. thaliana have accumulated their own uniqueness during its evolutionary trajectory (Francki \& Appels, 2007), and not all findings may be relevant for Streptocarpus. Continuous advances in next generation sequencing technologies allow an ever growing set of data to be acquired and greatly accelerate the progress of revealing the genetics in non-model plants. In Streptocarpus, the chloroplast genome, a transcriptome set, and a genetic map have already been published using 
next generation sequencing (Chiara et al., 2013; Chen et al., 2018; Kyalo et al., 2018). With those data available, it may be possible that the next studies may be able to reveal the molecular and physiological regulatory networks underlying the development of Streptocarpus. Not only proposing a genetic mechanism, but also carrying out functional confirmatory experiments through genetic modifications are needed to fully understand the molecular programme in Streptocarpus. Genetic tools, such as transformation and mutagenesis, have been developed mainly for African Violets, the former Saintpaulia, one of most popular ornamentals in the predominantly caulescent subgenus Streptocarpella in Streptocarpus (Kushikawa et al., 2001; Da Silva et al., 2017). Virus-iniduced gene silencing was also reported in S. rexii (Nishii et al., 2020). These techniques may be transferrable to the acaulescent subgenus Streptocarpus to examine the functions of the genes involved in its shoot development.

Our understanding of the link between environmental factors and plant hormones in Streptocarpus is incomplete, it may be an important driving force for the evolution of anisocotyly and the phyllomorph (Burtt, 1970). These features have allowed the species to occupy vastly divergent habitats such as dark, cool and moist evergreen rainforests on the one hand, and open, hot and dry grasslands on the other. In the latter, anisocotyly allows the plants to even withstand frequent natural fires and regrow from the basal meristem. Moreover, the abscission zone allows it to reduce the lamina to survive the dry winters. This makes the unifoliates not hopeless monsters but highly adapted lineages that have diversified into over 40 species (Hilliard \& Burtt, 1971). The genus Streptocarpus harbours many intermediates between the three main growth forms and future studies may reveal the genetic cascades that allow a flexibility in development that over evolutionary times added $>170$ species to a genus that some would have regarded as "misfits" (Bell, 2008).

\section{Acknowledgements}

We are grateful for the support to KN by $\mathrm{P}$. Hollingsworth at Royal Botanic Garden Edinburgh (RBGE, UK), and A. Iwamoto at Kanagawa University (Japan) and H. Iida at Tokyo Gakugei University (Japan). This work was supported by RBGE's science and horticultural divisions. S. Barber, N. Kelso and A. Ensoll for their support in cultivating the research materials. The scanning electron microscope images were obtained at the University of Tokyo with the support by of $\mathrm{H}$. Ohba. Two anonymous reviewers are thanked for their constructive comments. This work was financially supported by the Edinburgh Botanic Garden (Sibbald) Trust and the Japan Society for the Promotion of Science [JSPS KAKENHI Grant Number 18K06375], and the Sumitomo Foundation. RBGE is supported by the Rural and Environment Science and Analytical Services Division (RESAS) in the Scottish Government.

Appendix I. Glossary of specific terms used in Streptocarpus studies, based on Jong and Burtt (1975). In the alphabetical order:

Acaulescents: Species without ordinary shoot structure. Each leaf is termed as phyllomorph and a phyllomorph represents the entity of the shoot. Unifoliate and rosulate Streptocarpus belong to acaulescent Streptocarpus.

Accessory phyllomorph: Sensu Jong (1970) equalling additional phyllomorphs; sensu Dubuc-Lebreux (1978), combining adventitious and subtending phyllomorphs; sensu Nishii et al. (2010) equals subtending phyllomorph.

Additional phyllomorph: Phyllomorph formed from the groove meristem of an existing phyllomorph.

Adventitious phyllomorph: Phyllomorph formed de novo randomly on the surface of the petiolode and do not originate from the groove meristem.

Anisocotyly: Unequal cotyledon development.

Basal meristem: The meristem located in the proximal region of lamina. It contributes for lamina expansion.

Caulescents: Species with ordinary shoot structure, leaf and stem and the shoot apical meristem.

Cotyledonary phyllomorph: The mature form of the macrocotyledon.

Groove meristem: The meristem located at the juxtaposition between lamina and petiolode. The inflorescences or phyllomorph primordia initiate from the groove meristem. 
Isocotyly: Equal cotyledon development.

Macrocotyledon: The larger cotyledon in a pair of cotyledons, showing continuous enlargement ability.

Microcotyledon: The smaller cotyledon in a pair of cotyledons.

Petiolode meristem: The meristem contributes to the elongation and thickening of the petiolode.

Petiolode: The stalk of a phyllomorph. It retains the mixed nature between stem and petiole.

Phyllomorph: The leafy unit of acaulescent Streptocarpus. A phyllomorph is consisted with the lamina and petiolode.

Plurifoliates: Intermediates between unifoliate and rosulate. It forms only a few phyllomorph from the existing phyllomorph, or one at a time.

Rosulates: Acaulescent species with additional phyllomorph formed from the groove meristem of existing phyllomorph and form a false rosette.

Subtending phyllomorph: Phyllomorph forming from the groove meristem subtending a series of acropetally developing inflorescences in unifoliate Streptocarpus.

Unifoliates: Species only retain the macrocotyledon derived phyllomorph.

\section{Literature Cited}

ALABADÍ D., GALLEGO-BARTOLOMÉ J., ORLANDO L., GARCÍA-CÁRCEL L., RUBIO V., MARTÍNEZ C., FRIGERIO M., IGLESIAS-PEDRAZ J.M., ESPINOSA A., DENG X.W. \& M.A. BLÁZQUEZ 2008. Gibberellins modulate light signalling pathways to prevent Arabidopsis seedling de-etiolation in darkness. The Plant Journal 53: 324-335. https:// doi.org/10.1111/j.1365-313X.2007.03346.x

ALBERTE R.S. \& A.W. NAYLOR 1975. The role of cytokinins in chloroplast lamellar development. Plant Physiology 55: 1079-1081. https://doi.org/10.1104/ pp.55.6.1079

APPELGREN M. \& O. HEIDE 1972. Regeneration in Streptocarpus leaf discs and its regulation by temperature and growth substances. Physiologia Plantarum 27: 417-423. https://doi.org/10.1111/j.1399-3054.1972.tb03637.x

BARTHÉLÉMY D. \& Y. CARAGLIO 2007. Plant architecture: a dynamic, multilevel and comprehensive approach to plant form, structure and ontogeny. Annals of Botany 99: 375-407. https://doi.org/10.1093/aob/ mcl260

BARTON M.K. 2010. Twenty years on: the inner workings of the shoot apical meristem, a developmental dynamo.
Developmental Biology 341: 95-113. https://doi.org/ 10.1016/j.ydbio.2009.11.029

BELL A.D. 2008. Plant form: An illustrated guide to flowering plant morphology, Second Edition. Timber Press, Portland. p. 431.

BHARATHAN G., GOLIBER T.E., MOORE C., KESSLER S., PHAM T. \& N. SINHA 2002. Homologies in leaf form inferred from KNOXI gene expression during development. Science 296: 1858-1860. https://doi.org/10.1126/science.1070343

BOLDUC N. \& S. HAKE 2009. The maize transcription factor KNOTTED1 directly regulates the gibberellin catabolism gene ga2ox1. Plant Cell 21: 1647-1658. https://dx.doi.org/10.1105\%2Ftpc.109.068221

BURTT B.L. 1963. Studies in the Gesneriaceae of the Old World, XXIV: tentative keys to the tribes and genera. Notes from the Royal Botanic Garden Edinburgh 24: 205220.

BURTT B.L. 1970. Studies in the Gesneriaceae of the Old World XXXI: some aspects of functional evolution. Notes from the Royal Botanic Garden Edinburgh 30: 1-9.

BYRNE M.E., BARLEY R., CURTIS M., ARROYO J.M., DUNHAM M., HUDSON A. \& R.A. MARTIENSSEN 2000. Asymmetric leaves1 mediates leaf patterning and stem cell function in Arabidopsis. Nature 408: 967-971. https://doi.org/10.1038/35050091

CHAUDHURY A., POWER J.B. \& M.R. DAVEY 2010. High frequency direct plant regeneration from leaf and petals of Cape Primrose (Streptocarpus). Journal of Crop Science and Biotechnology 13: 107-112. https://doi.org/ 10.1007/s12892-010-0006-y

CHEN Y.Y., NISHII K., SPADA A., WANG C.N., SAKAKIBARA H., KOJIMA M., WRIGHT F., MACKENZIE K. \& M. MÖLLER 2017. Cytokinin biosynthesis ISOPENTENYLTRANSFERASE genes are differentially expressed during phyllomorph development in the acaulescent Streptocarpus rexii (Gesneriaceae). South African Journal of Botany 109: 96111. https://doi.org/10.1016/j.sajb.2016.12.010

CHEN Y.Y., NISHII K., BARBER S., HACKETT C., KIDNER C.A., GHARBI K., NAGANO A.J., IWAMOTO A. \& M. MÖLLER 2018. A first genetic map in the genus Streptocarpus generated with RAD sequencing based SNP markers. South African Journal of Botany 117: 158-168. https://doi.org/10.1016/ j.sajb.2018.05.009

CHIARA M., HORNER D.S. \& A. SPADA 2013. De novo assembly of the transcriptome of the non-model plant Streptocarpus rexii employing a novel heuristic to recover locus-specific transcript clusters. PLoS ONE 8: e80961. https://doi.org/10.1371/journal.pone.0080961 
CHITWOOD D.H., HEADLAND L.R., RANJAN A., MARTINEZ C.C., BRAYBROOK S.A., KOENIG D.P., KUHLEMEIER C., SMITH R.S. \& N.R. SINHA 2012. Leaf asymmetry as a developmental constraint imposed by auxin-dependent phyllotactic patterning. Plant Cell 24: 2318-2327. https://doi.org/10.1105/ tpc.112.098798

COWLING R.J. \& HARBERD N.P. 1999. Gibberellins control Arabidopsis hypocotyl growth via regulation of cellular elongation. Journal of Experimental Botany 50: 1351-1357. https://doi.org/10.1093/jxb/50.337.1351

CROCKER C.W. 1861["1860"]. Notes on the germination of certain species of Cyrtandreae. Journal of the Proceedings of the Linnean Society, Botany 5: 65-66.

CRONK Q.C.B. \& M. MÖLLER 1997. Strange morphogenesis - organ determination in Monophyllaea. Trends in Plant Science 2: 327-328. https://doi.org/ 10.1016/S1360-1385(97)84614-6

DA SILVA J.A.T., DEWIR Y.H., WICAKSONO A., SAHIJRAM L., KIM H., ZENG S., CHANDLER S.F. \& M. HOSOKAWA 2017. African violet (Saintpaulia ionantha $\mathrm{H}$. Wendl.): classical breeding and progress in the application of biotechnological techniques Folia Horticulture 29: 99-111. https://doi.org/10.1515/fhort2017-0010

DEWITTE W., CHIAPPETTA A., AZMI A., WITTERS E., STRNAD M., REMBUR J., NOIN M., CHRIQUI D. \& H. VAN ONCKELEN 1999. Dynamics of cytokinins in apical shoot meristems of a day-neutral tobacco during floral transition and flower formation. Plant Physiology 119: 111-121. https://doi.org/10.1104/ pp.119.1.111

DUBUC-LEBREUX M.A. 1976. Effets de quelques régulateurs de croissance sur le phyllomorphe cotylédonaire de Streptocarpus wendlandii Sprenger (Gesneriaceae). Annales des Sciences Naturelles, Botanique sér 12, 17: 259-276.

DUBUC-LEBREUX M.A. 1978. Modification of the unifoliate habit of Streptocarpus wendlandii and Streptocarpus michelmorel by some growth regulators. Phytomorphology 28: 224-238.

DUBUC-LEBREUX M.A. \& J. VIETH 1975. Boutures de phyllomorphes de Streptocarpus wendlandii Sprenger. Acta Botanica Neerlandica 24: 305-313.

DUBUC-LEBREUX M.A. \& J. VIETH 1976. Effets de quelques régulateurs de croissance sur la morphologic florale et inflorescentielle de Streptocarpus rexii (Hook.) Lindl. (Gesneriacées). Bulletin de la Société Botanique de France 123: 273-291.

ESAU K. 1977. Anatomy of seed plants. Second Edition. John Wiley \& Sons, Inc., New York. p. 572.
EZURA H. \& N.P. HARBERD 1995. Endogenous gibberellin levels influence in-vitro shoot regeneration in Arabidopsis thaliana (L.) Heynh. Planta 197: 301-305. https://doi.org/10.1007/BF00202651

FRANCKI M. \& R. APPELS 2007. Comparative genomics and crop improvement. In: BROWN J.R. (ed.), Comparative genomics, basic and applied research. First Edition. CRC Press, New York. pp. 321-334.

GAN S. \& R.M. AMASINO 1996. Cytokinins in plant senescence: From spray and pray to clone and play. BioEssays 18: 557-565. https://doi.org/10.1002/ bies.950180707

GOLZ J.F., ROCCARO M., KUZOFF R. \& A. HUDSON 2004. GRAMINIFOLIA promotes growth and polarity of Antirrhinum leaves. Development 131: 3661-3670. https://doi.org/10.1242/dev.01221

HAKE S., SMITH H.M.S., HOLTAN H., MAGNANI E., MELE G. \& J. RAMIREZ 2004. The role of KNOX genes in plant development. Annual Review of Cell and Developmental Biology 20: 125-151. https://doi.org/ 10.1146/annurev.cellbio.20.031803.093824

HARRISON J. 2002. Developmental genetics and evolution of plant form in Streptocarpus. Ph.D. thesis, University of Edinburgh, Edinburgh.

HARRISON J., MÖLLER M., LANGDALE J., CRONK Q.C.B. \& A. HUDSON 2005. The role of KNOX genes in the evolution of morphological novelty in Streptocarpus. Plant Cell 17: 430-443. https://doi.org/ 10.1105/tpc.104.028936

HAY A. \& M. TSIANTIS 2010. KNOX genes: versatile regulators of plant development and diversity. Development 137: 3153-3165. https://doi.org/10.1242/ dev.030049

HILLIARD O.M. \& B.L. BURTT 1971. Streptocarpus. An African plant study. Natal University Press, Pietermaritzburg. p. 410.

HUANG B.-H., NISHII K, WANG C.N. \& M. MÖLLER 2019. Quantitative assessment of the anisocotyly in Haberlea rhodopensis and Ramonda myconi. Edinburgh Journal of Botany 76: 377-391. https://doi.org/10.1017/ S0960428619000179

IKEUCHI M., OGAWA Y., IWASE A. \& K. SUGIMOTO 2016. Plant regeneration: cellular origins and molecular mechanisms. Development 143: 1442-1451. https:// doi.org/10.1242/dev.134668

IMAICHI R., NAGUMO S. \& M. KATO 2000. Ontogenetic anatomy of Streptocarpus grandis (Gesneriaceae) with implications for evolution of monophylly. Annals of Botany 86: 37-46. https://doi.org/ 10.1006/anbo.2000.1155 
IMAICHI R., OMURA-SHIMADATE M., AYANO M. \& M. KATO 2007. Developmental morphology of the caulescent species Streptocarpus pallidiflorus (Gesneriaceae), with implications for evolution of monophylly. International Journal of Plant Sciences 168: 251-260. https://doi.org/10.1086/510410

JASINSKI S., PIAZZA P., CRAFT J., HAY A., WOOLLEY L., RIEU I., PHILLIPS A., HEDDEN P. \& M. TSIANTIS 2005. KNOX action in Arabidopsis is mediated by coordinate regulation of cytokinin and gibberellin activities. Current Biology 15: 1560-1565. https://doi.org/10.1016/j.cub.2005.07.023

JONG K. 1970. Developmental aspects of vegetative morphology of Streptocarpus. Ph.D. thesis, University of Edinburgh, Edinburgh.

JONG K. \& B.L. BURTT 1975. The evolution of morphological novelty exemplified in the growth patterns of some Gesneriaceae. New Phytologist 75: 297-311. https://doi.org/10.1111/j.1469-8137.1975.tb01400.x

KIBA T., TAKEI K., KOJIMA M. \& H. SAKAKIBARA 2013. Side-chain modification of cytokinins controls shoot growth in Arabidopsis. Developmental Cell 27: 452461. https://doi.org/10.1016/j.devcel.2013.10.004

KUSHIKAWA S., HOSHINO Y. \& M. MII 2001. Agrobacterium-mediated transformation of Saintpaulia ionantha Wendl. Plant Science 161: 953-960. https:// doi.org/10.1016/S0168-9452(01)00496-4

KYALO C.M, GICHIRA A.W, LI Z.Z, SAINA J.K, MALOMBE I, HU G.W. \& Q.F. WANG 2018. Characterization and comparative analysis of the complete chloroplast genome of the critically endangered species Streptocarpus teitensis (Gesneriaceae). BioMed Research International 2018: 1507847. https:// doi.org/10.1155/2018/1507847

LEYSER O. 2018. Auxin signaling. Plant Physiology 176: 465-479. https://dx.doi.org/10.1104\%2Fpp.17.00765

LINDLEY J. 1828. Streptocarpus rexii. Cape Streptocarpus. The Botanical Register: Consisting of Coloured Figures of Exotic Plants Cultivated in British Gardens; with their History and Mode of Treatment 14: 1173.

LO K.H., GILES K.L. \& V.K. SAWHNEY 1997. Histological changes associated with acquisition of competence for shoot regeneration in leaf discs of Saintpaulia ionantha $\times$ confusa hybrid (African violet) cultured in vitro. Plant Cell Reports 16: 421-425. https:/ /doi.org/10.1007/BF01146786

LOMBARDI-CRESTANA S., DA SILVA AZEVEDO M., E SILVA G.F., PINO L.E., APPEZZATO-DAGLÓRIA B., FIGUEIRA A., NOGUEIRA F.T. \& L.E.
PERES 2012. The tomato (Solanum lycopersicum cv. Micro-Tom) natural genetic variation $R g 1$ and the DELLA mutant procera control the competence necessary to form adventitious roots and shoots. Journal of Experimental Botany 63: 5689-5703. https://doi.org/ 10.1093/jxb/ers221

LONG J.A., MOAN E.I., MEDFORD J.I. \& M.K. BARTON 1996. A member of the KNOTTED class of homeodomain proteins encoded by the STM gene of Arabidopsis. Nature 379: 66-69. https://doi.org/10.1038/ 379066a0

MANTEGAZZA R., MÖLLER M., HARRISON C.J., FIOR S., DE LUCA C. \& A. SPADA 2007. Anisocotyly and meristem initiation in an unorthodox plant, Streptocarpus rexii (Gesneriaceae). Planta 225: 653-663. https://doi.org/10.1007/s00425-006-0389-7

MANTEGAZZA R., TONONI P., MÖLLER M. \& A. SPADA 2009. WUS and STM homologs are linked to the expression of lateral dominance in the acaulescent Streptocarpus rexii (Gesneriaceae). Planta 230: 529-542. https://doi.org/10.1007/s00425-009-0965-8

MAYER K.F., SCHOOF H., HAECKER A., LENHARD M., JÜRGENS G. \& T. LAUX 1998. Role of WUSCHEL in regulating stem cell fate in the Arabidopsis shoot meristem. Cell 95: 805-815. https:// doi.org/10.1016/S0092-8674(00)81703-1

MIYAWAKI K., MATSUMOTO-KITANO M. \& T. KAKIMOTO 2004. Expression of cytokinin biosynthetic isopentenyltransferase genes in Arabidopsis: tissue specificity and regulation by auxin, cytokinin, and nitrate. Plant Journal 37: 128-138. https://doi.org/ 10.1046/j.1365-313X.2003.01945.X

MIYAWAKI K., TARKOWSKI P., MATSUMOTOKITANO M., KATO T., SATO S., TARKOWSKA D., TABATA S., SANDBERG G. \& T. KAKIMOTO 2006. Roles of Arabidopsis ATP/ADP isopentenyltransferases and tRNA isopenteny ltransferases in cytokinin biosynthesis. Proceedings of the National Academy of Sciences of the United States of America 103: 16598-16603. https://doi.org/10.1073/pnas.0603522103

MÖLLER M. \& Q.C.B. CRONK 2001. Evolution of morphological novelty: a phylogenetic analysis of growth patterns in Streptocarpus (Gesneriaceae). Evolution 55: 918-929. https://doi.org/10.1111/j.00143820.2001.tb00609.x

NAYLOR E.E. \& B. JOHNSON 1937. A histological study of vegetative reproduction in Saintpaulia ionantha. American Journal of Botany 24: 673-678. https://doi.org/ 10.1002/j.1537-2197.1937.tb09164.x

NISHII K., KUWABARA A. \& T. NAGATA 2004. Characterization of anisocotylous leaf formation in Streptocarpus wendlandii (Gesneriaceae): Significance of 
plant growth regulators. Annals of Botany 94: 457-467. https://doi.org/10.1093/aob/mch160

NISHII K. \& T. NAGATA 2007. Developmental analyses of the phyllomorph formation in the rosulate species Streptocarpus rexii (Gesneriaceae). Plant Systematics and Evolution 265: 135-145. https://doi.org/10.1007/s00606007-0515-4

NISHII K, MÖLLER M., KIDNER C.A, SPADA A., MANTEGAZZA R., WANG C.N. \& T. NAGATA 2010. A complex case of simple leaves: indeterminate leaves co-express ARP and KNOX1 genes. Development, Genes and Evolution 220: 25-40. https://doi.org/10.1007/ s00427-010-0326-4

NISHII K., WANG C.N., SPADA A., NAGATA T. \& M. MÖLLER 2012a. Gibberellin as a suppressor of lateral dominance and inducer of apical growth in the unifoliate Streptocarpus wendlandii (Gesneriaceae). New Zealand Journal of Botany 50: 267-287. https://doi.org/10.1080/ 0028825X.2012.671775

NISHII K., NAGATA T., WANG C.N. \& M. MÖLLER 2012b. Light as environmental regulator for germination and macrocotyledon development in Streptocarpus rexii (Gesneriaceae). South African Journal of Botany 81: 5060. https://doi.org/10.1016/j.sajb.2012.05.003

NISHII K., HO M.J., CHOU Y.W., GABOTTI D., WANG C.N., SPADA A. \& M. MÖLLER 2014. GA2 and GA20-oxidase expressions are associated with the meristem position in Streptocarpus rexii (Gesneriaceae). Plant Growth Regulation 72: 123-140. https://doi.org/ 10.1007/s10725-013-9844-1

NISHII K., HUANG B.H., WANG C.N. \& M. MÖLLER 2017. From shoot to leaf: step-wise shifts in meristem and KNOX1 activity correlate with the evolution of a unifoliate body plan in Gesneriaceae. Development Genes and Evolution 227: 41-60. https://doi.org/10.1007/ s00427-016-0568-x

NISHII K., WRIGHT F., CHEN Y.Y. \& M. MÖLLER 2018. Tangled history of a multigene family: The evolution of ISOPENTENYLTRANSFERASE genes. PLoS One 13: e0201198. https://doi.org/10.1371/ journal.pone. 0201198

NISHII K., FEI Y., HUDSON A., MÖLLER M. \& A. MOLNAR 2020. Virus-induced gene silencing in Streptocarpus rexii (Gesneriaceae). Molecular Biotechnology. https://doi.org/10.1007/s12033-02000248-w

NOEL A.R.A. \& J. VAN STADEN 1975. Phyllomorph senescence in Streptocarpus molweniensis. Annals of Botany 39: 921-929. https://doi.org/10.1093/oxfordjournals. aob.a085010

OSUGI A. \& H. SAKAKIBARA 2015. Q\&A: How do plants respond to cytokinins and what is their importance?
BMC Biology 13: 102. https://dx.doi.org/10.1186\%2 Fs12915-015-0214-5

ROSENBLUM I.M. \& D.V. BASILE 1984. Hormonalregulation of morphogenesis in Streptocarpus and its relevance to evolutionary history of the Gesneriaceae. American Journal of Botany 71: 52-64.

RUPP H. M., FRANK M., WERNER T., STRNAD M. \& T. SCHMULLING 1999. Increased steady state mRNA levels of the STM and KNAT1 homeobox genes in cytokinin overproducing Arabidopsis thaliana indicate a role for cytokinins in the shoot apical meristem. Plant Journal 18: 557-563. https://doi.org/10.1046/j.1365313x.1999.00472.x

SAUEREGGER J. \& A. WEBER 2004. Factors controlling initiation and orientation of the macrocotyledon in anisocotylous Gesneriaceae. Edinburgh Journal of Botany 60: 467-482. https:// doi.org/10.1017/S0960428603000350

SCHOOF H., LENHARD M., HAECKER A., MAYER K.F., JURGENS G. \& T. LAUX 2000. The stem cell population of Arabidopsis shoot meristems is maintained by a regulatory loop between the CLAVATA and WUSCHEL genes. Cell 100: 635-644. https://doi.org/ 10.1016/s0092-8674(00)80700-x

SIEGFRIED K.R., ESHED Y., BAUM S.F., OTSUGA D., DREWS G.N. \& J.L. BOWMAN 1999. Members of the $Y A B B Y$ gene family specify abaxial cell fate in Arabidopsis. Development 126: 4117-4128.

SINGH D.P., FILARDO F.F., STOREY R., JERMAKOW A.M., YAMAGUCHI S. \& S.M. SWAIN 2010. Overexpression of a gibberellin inactivation gene alters seed development, KNOX gene expression, and plant development in Arabidopsis. Physiologia Plantarum 138: 74-90. https://doi.org/10.1111/j.1399-3054.2009. 01289.x

SU Y.H., LIU Y.B. \& X.S. ZHANG 2011. Auxin-cytokinin interaction regulates meristem development. Molecular Plant 4: 616-625. https://doi.org/10.1093/mp/ssr007

SUN T.P. 2010. Gibberellin signal transduction in stem elongation \& leaf growth. In: DAVIES P.J. (ed.), Plant hormones biosynthesis, signal transduction, action!. Springer, Dordrecht. pp. 308-328.

THEISSEN G. 2006. The proper place of hopeful monsters in evolutionary biology. Theory in Biosciences 124: 349369. https://doi.org/10.1016/j.thbio.2005.11.002

TIMMERMANS M.C.P., HUDSON A., BECRAFT P.W. \& T. NELSON 1999. ROUGH SHEATH2: a Myb protein that represses knox homeobox genes in maize lateral organ primordia. Science 284: 151-153. https://doi.org/10.1126/science.284.5411.151

TONONI P., MÖLLER M., BENCIVENGA S. \& A. SPADA 2010. GRAMINIFOLIA homolog expression 
in Streptocarpus rexii is associated with the basal meristems in phyllomorphs, a morphological novelty in Gesneriaceae. Evolution \& Development 12: 61-73. https://doi.org/10.1111/j.1525-142X.2009.00391.x

TSIANTIS M., SCHNEEBERGER R., GOLZ J.F., FREELING M. \& L.A. LANGDALE 1999. The maize rough sheath 2 gene and leaf development programs in monocot and dicot plants. Science 284: 154-156. https:// doi.org/10.1126/science.284.5411.154

TSUKAYA H. 1997. Determination of the unequal fate of cotyledons of a one-leaf plant, Monophyllaea. Development 124: 1275-1280.

VAN STADEN J. 1973. Changes in endogenous cytokinin levels during abscission and senescence of Streptocarpus leaves. Journal of Experimental Botany 24: 667-671. https://doi.org/10.1093/jxb/24.4.667

WAITES R., SELVADURAI H.R.N., OLIVER I.R. \& A. HUDSON 1998. The PHANTASTICA gene encodes a MYB transcription factor involved in growth and dorsoventrality of lateral organs in Antirrhinum. Cell 93: 779-789. https://doi.org/10.1016/S0092-8674(00) 81439-7
WEBER A. 2004. Gesneriaceae. In: KUBITZKI K. (ed.), The families and genera of vascular plants. Volume 7. Springer, Berlin. pp. 63-158.

XU J., CHEN L., SUN H., WUSIMAN N., SUN W., LI B., GAO Y., KONG J., ZHANG D., ZHANG X., XU H. \& X. YANG 2019. Crosstalk between cytokinin and ethylene signalling pathways regulates leaf abscission in cotton in response to chemical defoliants. Journal of Experimental Botany 70: 1525-1538. https://doi.org/ 10.1093/jxb/erz036

YAMAGUCHI S. 2008. Gibberellin metabolism and its regulation. Annual Reviews of Plant Biology 59: 225-251. https://doi.org/10.1146/annurev.arplant.59.032607.092804

YANAI O., SHANI E., DOLEZAL K., TARKOWSKI P., SABLOWSKI R., SANDBERG G., SAMACH A. \& N. ORI 2005. Arabidopsis KNOXI proteins activate cytokinin biosynthesis. Current Biology 15: 1566-1571. https://doi.org/10.1016/j.cub.2005.07.060

ZHANG T.Q., LIAN H., ZHOU C.M., XU L., JIAO Y. \& J.W. WANG 2017. A two-step model for de novo activation of WUSCHEL during plant shoot regeneration. Plant Cell 29: 1073-1087. https://doi.org/ 10.1105/tpc.16.00863 